\title{
A BALANCED GEOLOGICAL CROSS-SECTION ALONG KOHALPUR - SURKHET AREA OF SUB-HIMALAYAN RANGE, MID-WESTERN NEPAL
}

\author{
Nirmal Kafle $^{1}$, Lelin Raj Dhungel ${ }^{2}$, Kamala Kanta Acharya ${ }^{3}$, Megh Raj Dhital ${ }^{3}$ \\ ${ }^{I}$ Department of Civil Engineering, Khwopa College of Engineering, Bhaktapur, Nepal \\ ${ }^{2}$ Department of Irrigation, Government of Nepal, Nepal \\ ${ }^{3}$ Central Department of Geology, Central Campus, Tribhuvan University, Kirtipur, Nepal
}

\begin{abstract}
The Sub-Himalayans Zone comprises a tectonic wedge of syn-orogenic sediments along the outer Himalayan Belt. Sediments are integrated into the accretionary prism from the foreland Indo-Gangetic plain, undergo a tectonic cycle within it, and eventually are eroded. The structural sketch map unveils westward-plunging arcuate structures on the leading location of the Outer Belt. A balanced cross-section has been constructed across the Sub-Himalayan Hills of the Kohalpur-Surkhet region of mid-western Nepal in order to determine the structural geometry of the region and to calculate tectonic shortening. The mid-western Nepal Sub-Himalaya has an emergent splay fan geometry with no major prevailing thrust contains the Main Boundary Thrust (MBT), the Bheri Thrust, the Babai Thrust and the Main frontal Thrust (MFT) which are all imbricate of the main decollment which ramp up-section through the $5 \mathrm{~km}$ thick tectonic sedimentary prism. North-south shortening across the mid-western Nepal, Kohalpur-Surkhet section has been approximately 29 km, or 55\% shortening.
\end{abstract}

Keywords: Balanced Cross-Section, Sub-Himalayan, mid-western, MFT, MBT.

\section{Introduction}

The critical taper formed by orogenic belts can be divided into various parts in their front zone. As is the case for the Sub-Himalayan Zone of mid-western Nepal, the most frontal deformed part often corresponds to an accretionary wedge of synorogenic sediments incorporated from the foreland basin into the mountain belt. This unit constitutes an open system of material; because sediments are added to the wedge from the foreland and removed from it by erosion. According to Dahlen and Barr (1989), mature continental synorogenic accretionary wedges display critical-taper angles and can be in a volumetric steady state.

\footnotetext{
*Corresponding author: Nirmal Kafle

Department of Civil Engineering, Khwopa College of Engineering, Bhaktapur, Nepal

Email: nirmalkafle1917@gmail.com

(Received: 15 ${ }^{\text {th }}$ Nov 2017 Accepted: 08 ${ }^{\text {th }}$ April 2019)
}

As a consequence, to keep a balanced volume of sediments throughout time within the unit, the processes that withdraw material from the wedge (erosion or duplex subduction) must be strong enough to remove sufficient material from the wedge material within the wedge undergoes a burial cycle, from the fresh sediment in the foreland being incorporated into the prism, to the free, eroded sediment at the surface. This pattern is generally associated with thin-skinned deformation styles. The main morphotectonic units of the Himalayas south of Tibet include the High Himalayas, which are made of crystalline rocks and are bounded southward by the Main Central Thrust (MCT); and the Lesser Himalayas, which are made of metasedimentary rocks and are separated to the south by the Main Boundary Thrust (MBT). The last unit is the SubHimalayan Zone Fold-and-thrust Belt, which forms a Neogene accretionary wedge on the southern 


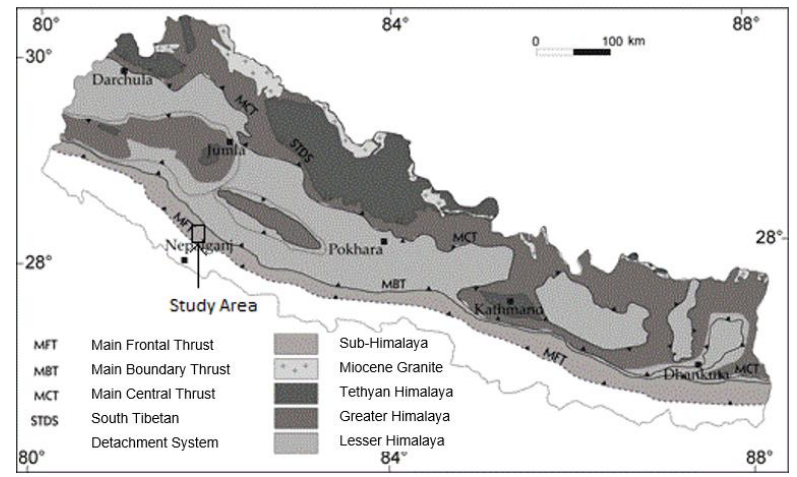

Fig. 1. Location map of the study area

foothills of the Himalayas that is deformed in a thinskinned style (Herail et al., 1986; Schelling, 1992; Mugnier et al., 1992, 1999a; Powers et al., 1998).

The main purpose of the present study is to establish the geology of Sub-himalayan rocksto workout the geological set up, structural framework and tectonics of the area to preapare balanced cross-section across the study area to determine the crustal shortening in the region based on balenced cross-section. The Balanced cross-section is prepared identifying the crustal transport direction for the thrust sheets applying ELLIOTT's bow and arrow rules. A reverent correction line along the direction of transport is choosen and dip-strike points are measured on it to draw a cross-section along the direction of transport. This paper discusses a structural section through the Sub - Himalayan (Churia) Hills of Mid - Western Nepal, which has been line - length balanced, and the implications of balancing the cross section for understanding the structural geometry and development of the Sub Himalayan foreland fold-thrust belt. Tectonic shortening across the Surkhet-Kohalpur SubHimalaya has been calculated from the balanced and restored sections. The study area is situated about 550 $\mathrm{km}$ west of the Kathmandu. It occupies a small part of the Sub Himalaya in mid-western Nepal (Fig. 1)

\section{Geological Setting and Stratigraphy}

The Sub-Himalayan fold-and-thrust belt was created by the deformed syn-orogenic series of the SubHimalayan Group (Mugnier et al., 1992, 1994; 1999a; Powers et al., 1998), above the northwardsubducting Indian plate. The series is located in the foothills of the Himalayas and comprises a succession of east-southeast-west-northwesttrending ridges that are perpendicular to the N10N308E compressional axis (Ni and Baraganzi, 1996; Jouanne et al.,1999).A few ridges are the geomorphological expression of active thrusts. These faults branch off of a gently north-dipping decollement (Raiverman et al., 1994; Galahaut and Chandler, 1992; Biswas, 1994). Therefore, only a few active thrusts beneath south-verging slices accommodate the shortening in the Sub-Himalayan Zone. The fold-and-thrust belt is bounded by the Main Boundary Thrust (MBT) to the north, and the Main Frontal Thrust (MFT) is the southernmost tectonic feature, characterized by Tertiary sediments overthrusting Quaternary (DeCelles et al., 1998a) which are amenable to structural analysis using the techniques of balancing cross-sections. It has been recognized to be valid in restoring deformed-state cross-sections and estimating absolute and relative contraction and extension across a given region (Bally et al., 1966; Dahlstrom, 1969; Elliot, 1983; Hossack, 1979; Cooper and Trayner, 1986).

Throughout Nepal the Sub-Himalayan Group of the Sub- Himalaya can be divided into three lithostratigraphic units, the Lower Siwaliks, the Middle Siwaliks and the Upper Siwaliks (Hagen, 1969; Itihara et al., 1972; West and Munthe, 1981: Herail et al., 1986) but it is divided under the four folds' classification system in the present study area namely Lower Siwaliks, Middle Siwaliks A, Middle Siwaliks B and Upper Siwaliks. The Lower Siwaliks constitute the lowest stratigraphic unit in the study area (Fig. 3). They are made up of very thick (more than $5 \mathrm{~m}$ ) alternating beds of red-purple, yellow, brown, and grey-green mudstone, calcareous mudstone, and shale with siltstone and medium- to fine-grained grey and green-grey sandstone intercalations. The mudstones and sandstones occur in almost equal proportions. There are pseudoconglomerate (of mud clasts) and calcrete zones within the strongly bioturbated mudstone. The succession is moderately to slightly indurated, moderately hard, and massive. The Lower Siwaliks are transitionally followed stratigraphically upsection by medium- to coarse-grained, grey, micaceous sandstones and red-purple or grey to green-grey mudstones with pseudoconglomerate intercalations. The proportion of sandstones is higher (i.e. up to 60 
$-70 \%)$ than that of mudstones (30-40\%). The sandstones are slightly indurated, soft, and loose to partially cemented by calcite. They form very thick to extremely thick beds ranging from 5 to $20 \mathrm{~m}$. These beds are gradually followed upwards by very thick $(5$ to $10 \mathrm{~m})$ grey mudstone beds exhibiting intense bioturbation. As the mudstone and sandstone beds have very contrasting resistance to weathering, they constitute a topography exhibiting alternating ridges (in sandstone) and furrows (in mudstone). This unit is conspicuous in the study area because of its beautiful cuestas observed near Harre and elsewhere. The cuestas are developed on very thick to extremely thick sandstones forming gentle dip slopes. This formation comprises very coarse-grained "pepperand-salt" coloured multi-storeyed sandstone beds of up to $25 \mathrm{~m}$ thickness and grading upwards into grey to dark grey mudstone beds with plant debris in their upper part. The proportion of sandstones varies from 65 to $75 \%$ and that of mudstone is about 25 to $35 \%$. The lower contact of the sandstone beds is scoured and sharp whereas the upper contact with the overlying siltstone and mudstone is gradual and imperceptible. Sometimes convolute bedding, load casts, ball and pillow structures, and flame structures are observed at the sole of the sandstone beds. Frequently pebbles and granules are found in the lower part of the sandstone beds which are infrequently cemented by calcite. Spectacular crossbedding and parallel bedding are seen in the sandstone beds. The mudstone beds are soft and feeble as well as strongly bioturbated; they are easily denuded by runoff. As a result, gullies and rills are developed on the mudstones. The Upper Siwaliks in the area are represented by thick to very thick ( 5 to $10 \mathrm{~m}$ ), loosely to well cemented cobble- and pebbleconglomerates and mudstones. The yellow-brown to grey-green mudstones constitute about $30-40 \%$ of the thickness whereas the yellow-brown conglomerates attain from 60 to $70 \%$ of its thickness. The uppermost about $50 \mathrm{~m}$ of the Upper Siwaliks is represented by loose and unconsolidated boulder beds containing sand and silt in its matrix.(Fig. 2).

\section{Structure of the Surkhet - Kohalpur region}

In the area of thick sedimentary pile, the basal decollement is found to lie at a greater depth. The number of the splay thrusts originating is such that this sedimentary pile gives rise to a series of horses. But in the case where sedimentary deposits form a thin skin, the thrust splay off the basal decollement, which constitute an imbricate stack or a Schuppen Structure.

In order to establish that a thrust belt is a thinskinned, it is necessary to demonstrate that thrust fault surfaces constitute irregular 'staircase' trajectories with long "flat" sections, parallel to bedding, separated by short ramps which cut across strata boundaries. (Boyler and Elliot, 1982). The rocks in the study area show smooth flats, parallel to bedding plane and steep ramps cutting through the bedding.

In the study area, three splay thrusts are observed. To the northern extremity, the first splay thrust is represented by the Bheri Thrust (Kayastha et al,.1999). It is a north-dipping thrust with the Lower Siwaliks in the hanging wall and the Upper Siwaliks in the footwall. The second tectonic displacement is represented by the Babai Thrust which is also northdipping and third one is the MFT (Fig 4).

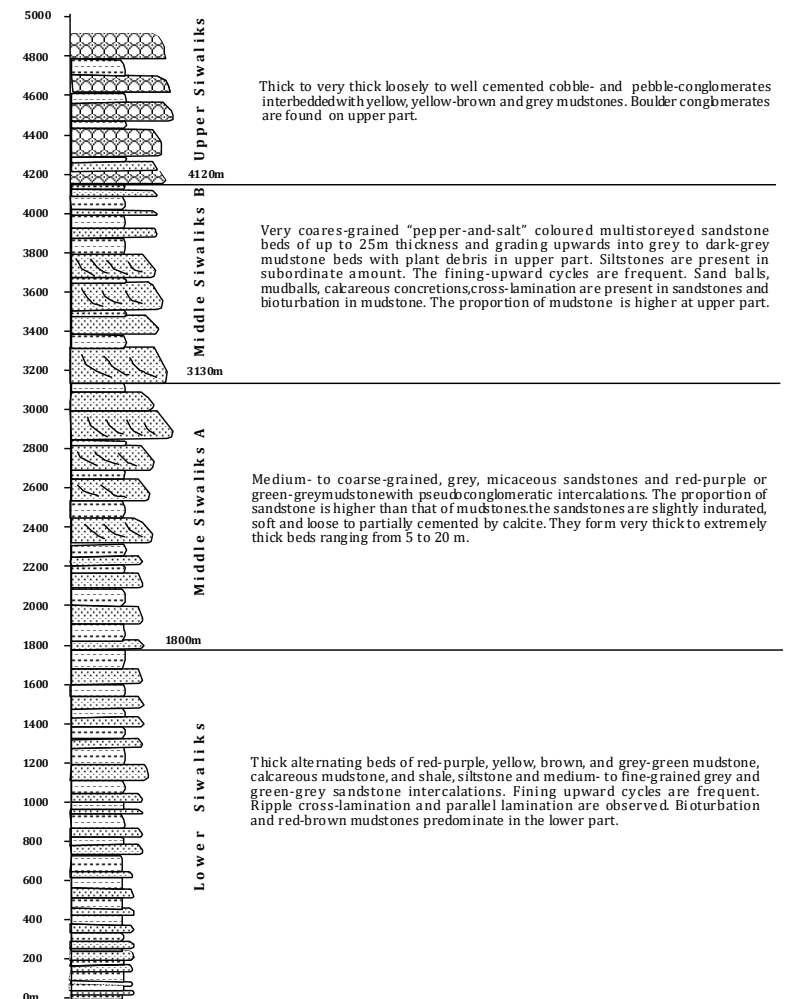

Fig. 2. Generalized columnar section of the midwestern Nepal Sub-Himalaya. 

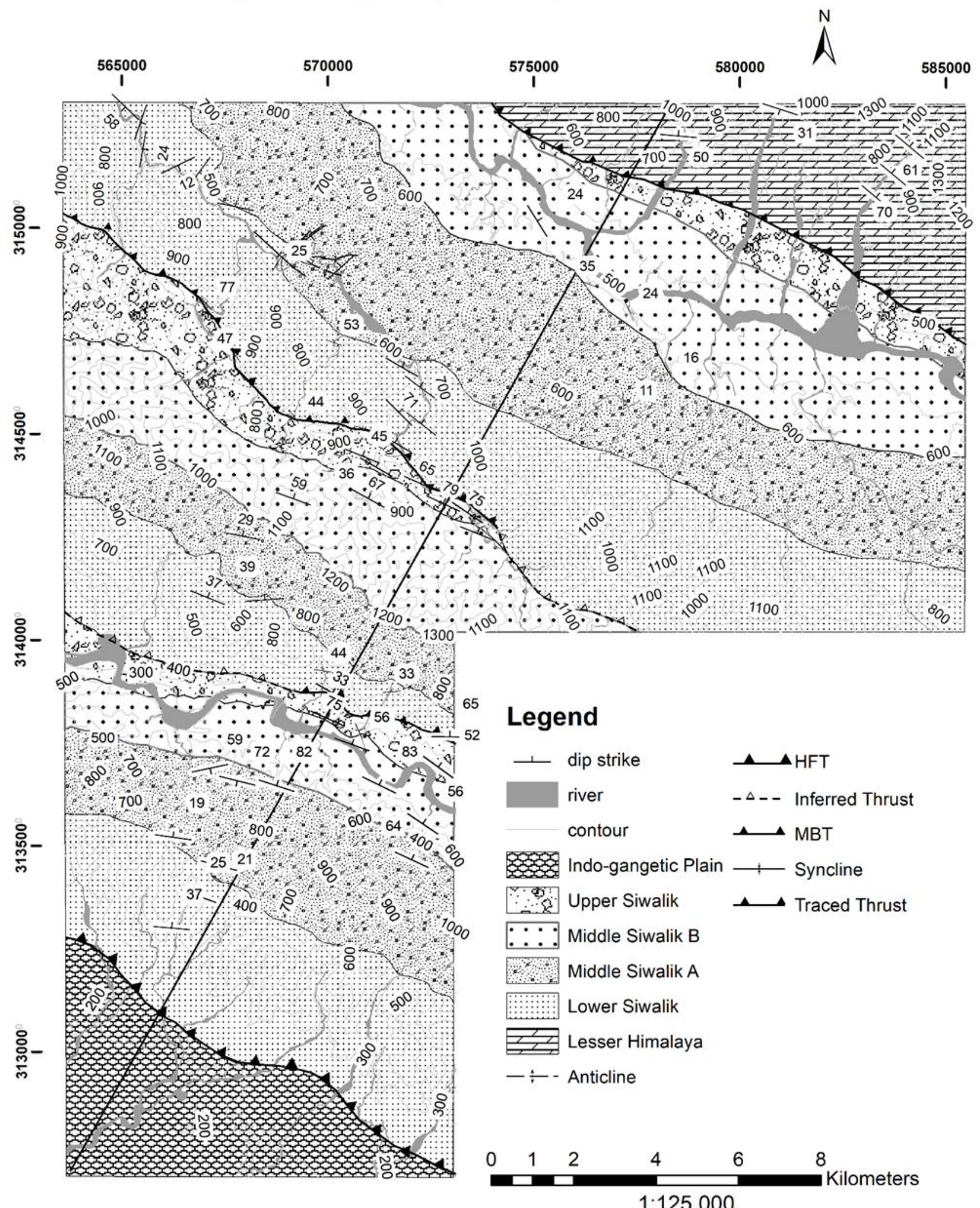

Fig. 3. Geological map of the Surkhet-Kohalpur region, mid-western Nepal 


\section{Legend}

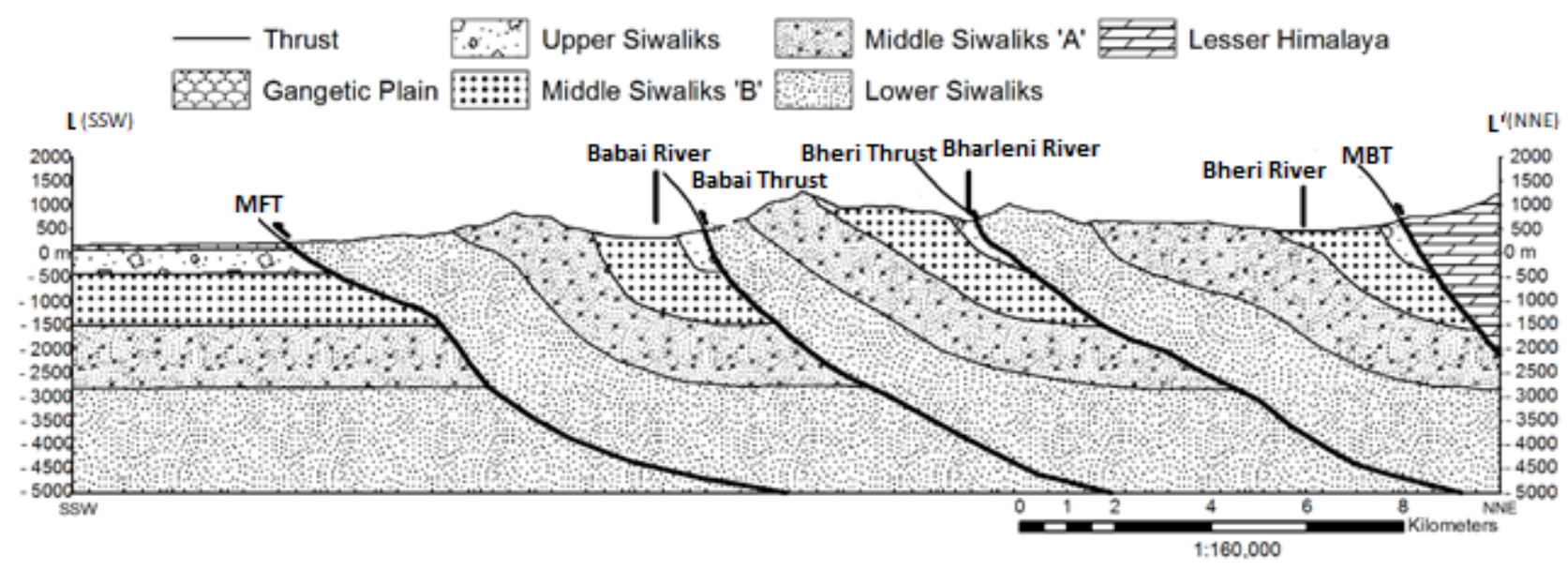

Fig. 4. Geological cross-section along the line $\mathrm{L}-\mathrm{L}^{\prime}$.

These three thrusts are responsible for the shorteningof the Sub-Himalayan. According to the theory of the origin of the low-angled thrust faults in the continental-continental collision zones, the resultant thrust migration should occur against the crustal transportation direction. Assuming the formation of the foreland migrating thrusts in the Sub-Himalayas (Schelling et al 1991), the Bheri Thrust should be the first splay, the Babai Thrust is the second and the MFT should be the third by origin.

\section{Balanced Cross-section}

In the study area after regional geological mapping, one section across Kohalpur-Surkhet region was chosen for the construction of balanced cross section. The section shows major structural outline and the intensity of thrusting are greater. The balanced crosssection prepared in the admissible one. The balanced cross-section shows the probable structural geometry of theSub-Himalayan Hills in the Kohalpur-Surkhet region. The section has been drawn perpendicular to the strikes of bedding and the trends of emergent thrust faults, and perpendicular to the general structural trend of the central Nepal Himalaya, and thus the line of section approximates the direction of shortening across the mid-western Nepal SubHimalaya. In the section the MFT represents the leading imbricate where fix line has been covered by the colluvium deposits. The gradual southward decrease of dip amount around Chisapani area indicates the MFT below the colluvial deposits. The thrust moves over the present coronial surface of the terai plain. Occurrence of about $1800 \mathrm{~m}$ (Fig 2) thick Lower Siwaliks in the hanging wall of the thrust suggest that the leading splay thrust branches off the main detachment thrust of the lower portion of the Lower Siwaliks. About $4900 \mathrm{~m}$ thick undisturbed sequence of the rock in the hanging wall of the thrust suggests that the Main Detachment Fault (MDF) lies at this depth in a more or less horizontal decollement surface. (Fig 4). The gradual flattening of bedding dips to the north within the Main Frontal Thrust sheet suggest that the MFT has an overall listric shape and that the MFT has approached the regional detachment fault, the Main Detachment Fault (MDF), under the surface exposure of the Babai Thrust (Fig 3). The lack of any fault bend anticlines within the sheet suggest that the MFT climbs directly to the surface from the MDF with no longer or intervening thrust flats.

About $1 \mathrm{Km}$ north of the MFT, the beds dip of about $50^{\circ}$ towards the north. The dip gradually goes on increasing towards north in the road section. At Deorali, the Middle Siwaliks A shows overturning. The cause of such rapid dip change is not clearly known only from the surface observation. However, the Babai Thrust should have played an important role. The overturned dip of the bed show difficulty of fault movement for the Babai Thrust of that area which is tried to show from the balanced crosssection (Fig. 5 a and 5 c). High angle of dipping of 
the bed suggest that the fault bedding cut of angle in the footwall ramp of the MFT in comparatively higher at depth because the dip of beds in the hanging wall block correspond to the cut off angle of the footwall.

In the section of Babai, the exposure of the Lower Siwaliks is again seen. This indicates the occurrence of another splay thrust. The exposure is about only $900 \mathrm{~m}$ thick sequence of the Lower Siwaliks along the thrust. This might indicates that, the splay thrust was originated from the higher level than the main detachment fault in the Lower Siwaliks and the deformation rate is high.

Babai River is $25^{\circ}-30^{\circ}$. Fault-bedding cut off angles are generally $30^{\circ}$ or less several kilometers below the syn-orogenic erosion surface (Elliot, 1980) and thus the fault-bedding cut-off angle between the Babai Thrust and the Upper Siwaliks sediments is probably not significantly greater than $30^{\circ}$. Therefore, the Babai Thrust is believed to have a hanging wall flat geometry. In addition, the extreme outcrop of the Lower Siwaliks sediments along the Babai Thrust in its hanging wall suggest that the Lower Siwaliks are a lithic unit in which thrust flats form. The corresponding Babai Thrust footwall thrust flat within or at the base of the Lower Siwaliks sediment is believed to coincide with the Main Detachment Fault (MDF).

The MDF is thus believed to lie at a depth of about $5 \mathrm{~km}$ (The thickness of Siwaliks in mid-western Nepal) underneath the mid-western Nepal Sub Himalaya (Fig. 4) As with the MFT, bedding orientation within the Babai Thrust sheet north of Babai river suggest that the Babai Thrust cuts directly up-section through the Sub-Himalayan sediments with no major intervening thrust- ramps.

From the Babai Thrust towards the north, bed dips at $40^{\circ}-50^{\circ}$ in Lower Siwaliks and it gradually decreases and again increases towards the Bheri Thrust which dips about $55^{\circ}-65^{\circ}$ due north. The fault-bedding cut off angle is not much significant which here shows at upper part, the hanging wall ramp geometry but it is believed to have an hanging wall flat geometry at the lower part of the thrust.

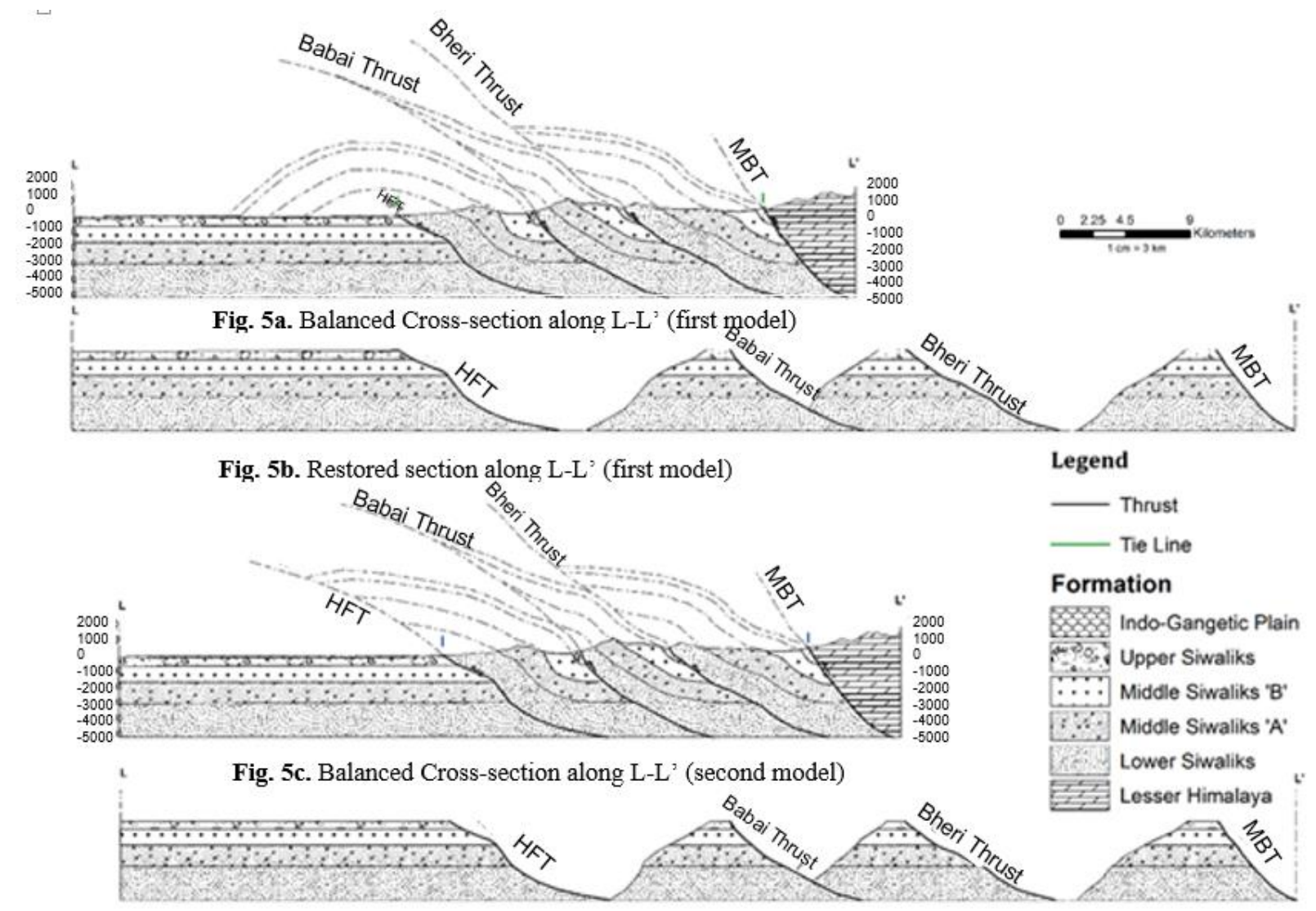

Fig. 5d. Restored section along L-L' (second model) 
Lesser Himalaya bedding foliation dips of about $60^{\circ}$ in the hanging wall of the MBT suggest that the MBT dips $60^{\circ}$ or more to the north of the surface. However, the MBT must flatten out as it approaches the MDF at a depth of about $5 \mathrm{~km}$ (Fig. $5 \mathrm{a}$ and $5 \mathrm{c}$ ). The MBT presently shows major displacement (rocks of the Lesser Himalayas thrust over the Tertiary sediments of the Sub-Himalayan wedge, according to Upreti, 1990; Mugnier et al., 1992). However, Holocene activation of the MBT has locally minor normal sense slip (0.5 mm/yr; Mugnier et al., 1994), thus suggesting that taper is overcritical in this area, which implies that the MBT is not currently accommodating tangible shortening. As a consequence, the overall shortening is accommodated mainly by the the Bheri Thrust, the Babai Thrust and the MFT in the study area.

The restored section shows that the basal decollement presumably lies below the Lower Siwaliks. The minimum crustal shortening from MBT to MFT is 29 km (Fig. 5b and 5d). The MFT, the Bheri Thrust and the Babai Thrust, all are the major shortening zones.

\section{Conclusion and Discussion}

A balanced cross-section constructed across the midwestern Nepal Sub-Himalaya in the SurkhetKohalpur region suggests the presence of an underlying basal detachment, the Main Detachment Fault (MDF), at a depth of about $5 \mathrm{~km}$. The techniques were developed primarily in the frontal fold-thrust belt of the eastern Canadian Rocky Mountains, characterized by folded and faulted, nonmetamorphosed sedimentary sequences, like the SubHimalaya. The Main Boundary Thrust (MBT), the Bheri Thrust, the Babai Thrust and the Main Frontal Thrust (MFT) are all emergent splay thrusts of the Main Detachment Fault and cut up-section through the $5 \mathrm{~km}$ thick section of Sub-Himalayan sediments to the surface without any major intervening thrustflats. The mid-western Nepal Sub-Himalaya thus displays an emergent imbricate-fan geometry. Total north-south shortening across the Surkhet-Kohalpur section, south of the Main Boundary Thrust, is approximately $29 \mathrm{~km}$, or $55 \%$.

\section{References}

[1] Bally, A. W., Gordy P. L., and Stewart G. A. (1966). Structure, seismic data and orogenic evolution of southern Canadian Rocky Mountains. Bull. Can. Petrol. Geol., 14: 337-381.

[2] Biswas, S. K. (1994). Status exploration for hydrocarbonsin Sub-Himalayan basin of India and future trends: Himalayan Geology, Vol. 15, p. 283300 .

[3] Boyer, S.M. and Elliot, D. (1982). Thrust system, Bull. Am. Ass. Petrol. Geol., 66, pp. 1196-1230.

[4] Cooper, M. A., and Trayner, P. M. (1986). Thrust surface geometry: implications for thrust -belt evolution and section-balancing techniques. Jour. Structural Geol., 8: 305- 312.

[5] Dahlen, F. A., and Barr, T. (1989). Brittle frictional mountain building, 1. Deformation and mechanical energy budget. Journal of Geophysical Research, Vol. 94, B4, 1: 3906-3922.

[6] Dahlstrom, C. D. A.(1969). Balanced cross-sections. Can. jour. Earth Sci., 6: 743-757.

[7] DeCelles, P. G., Gehrels, G. E., Quade, J., Ojha, T. P. and Kapp, P. A. (1998a). Neogene foreland basin deposits, erosional unroofing and the kinematic history of the Himalayan fold-and-thrust belt, Western Nepal.Geological Society of America Bulletin, Vol. 110/1, 2-21.

[8] Elliot, D. (1980). Balanced cross-sections, the methods and programs. Unpublished manuscript.

[9] Elliot, D. (1983). The construction of balanced crosssections. Jour. Structural Geol., 5: 101- 115.

[10] Galahaut, V. K., and Chandler, R. (1992). On the active tectonics of the Dehra Dun region from Observations of ground elevation changes.Journal of the Geological Society of India, Vol. 39, 61-68.

[11] Hagen, T., (1969). Report on the geological Surveouy of Nepal. Preliminary reconnaissance.Denkschriftender Schweizerischen Naturforchenden Gesellschaft, Memoires dela Societte Helvetique des Sciences naturees, Zurich, $86,185$.

[12] Herail, G., MascJe, G. and Delcaillau, B. (1986). Les Sub-Himalayans de I'Himalaya du Nepal: un example 
d'evolution geodynamique d'un prisme d'accretion intracontinental. Sciences de la Terre, Nancy, 47: 155182.

[13] Hossack, J. (1979). The use of balanced cross-sections in the calculation of orogenic contraction:a review. Jour. Geol. Soc. London, 136: 705-711.

[14] Itihara, M., Shibasaki, T. and Miyamoto,N. (1972). Photogeological survey of the Sub-HimalayanRanges and the Terrai Plain, Southeastern Nepal. jour. O/ Geosciences, Osaka City Univ., 15(4): 77-98.

[15] Kayastha, N.B., Pradhan, U.M.S., Shrestha, R.B., KC, Shyam, Subedi, D.N. and Sharma, S.R. (1999). Petroleum Exploration Promotion Project, Ministry of Industry 1999.

[16] Jouanne, F., Mugnier, J-L., Pandey, M. R., Gamond, J-F., Le Fort, P., Serrurier, L., Vigny, C., Avouac, J-P and Idylhim members. (1999). Oblique convergence in the Himalayas of western Nepal deduced from preliminary results of GPS measurements.Geophysical Research Letters, Vol. 26, 1933-1936.

[17] Mascle, G., He'rail, G., Van Haver, T. and Delcaillau, B. (1986). Structure et evolution des bassins d'e'pisutureet de pe'risuture lie's a' la châne himalayenne. Socie'te'Nationale Elf Aquitaine Production, BCREDP 10, Pau, pp. 181-203.

[18] Mugnier, J. L., Leturmy, P., Mascle, G., Huyghe, P., Chalaron, E., Vidal, Husson, G., L. and Delcaillau, B. (1999a). The Sub-Himalayans of Western Nepal I: Geometry and kinematics. Journal of Asian Earth Sciences, 17, pp. 629-642.

[19] Mugnier, J-L., Huyghe, P., Chalaron, E. and Mascle, G. (1994). Recent movements along the Main Boundary Thrust of the Himalayas. normal faulting in an over critical thrust. wedge? Tectonophysics, Vol. 238, pp. 199-215.

[20] Mugnier, J-L, Mascle, G., andFaucher, T. (1992). La structuredes Sub-Himalayan de l'Ouest Nepal: un Prism accretion intracontinental. Bulletin de la Socie'te' Ge'ologique deFrance, Vol. 163-5, pp. 585-595.

[21] Munthe, J., Dangol, B., Huthchison, J. H., Kean, W. F., Munthe, K. and West, R. M. (1983), New fossil discoveries from the Miocene of Nepal include a Hominoid, Nature, 303 (5915), pp. 331-333.

[22] Ni, J., and Baraganzi, M. (1996). Seismotectonics of the Himalayan collision zone: geometry of the underthrusting Indian plate beneath the Himalaya. Journal of Geophysical Research, Vol. 89, pp. 1147-
1163.

[23] Powers, P. M., Lillie, R. J. and Yeats, S. (1998). Structure and of the Kangra and Dehra Dun reentrants, Sub-Himalaya, India: Geological Society of America Bulletin, v. 110, pp. 1010-1027.

[24] Raiverman, V., Srivastava, A. K. and Prasad, D. N. (1994). Structural style in north-western Himalayan foothills, in Kumar G. and Phadtare N. R., eds.: SubHimalayan foreland basin of Himalaya, v. 15, pp. 263-280.

[25] Schelling, D. (1991). A balanced cross-section through the eastern Nepal Sub-Himalayan Hills, Bagmati River region; implications for the structure of the southern Himalaya. Paper submitted to Tectonophysics.

[26] Upreti, B. N. (1990). An outline of the geology of far western Nepal: Journal of Himalayan Geology, Vol 1, pp. 93-102.

[27] West, R. M. and Munthe, J. (1981), Cenozoic vertebrate paleontology and stratigraphy of Nepal, Him. Geol., 11, pp. 18-27. 